\title{
Bioluminescent Vibrio fischeri Assays in the Assessment of Seasonal and Spatial Patterns in Toxicity of Contaminated River Sediments
}

\author{
Sergio Jarque, Petr Masner, Jana Klánová, Roman Prokeš and Ludek Bláha * \\ Faculty of Science, Research Centre for Toxic Compounds in the Environment (RECETOX), Masaryk University, Brno, Czech \\ Republic
}

Several bacteria-based assays, notably Vibrio fischeri luminescence assays, are often used as environmental monitoring tool for toxicity in sediments that may serve as both sinks and secondary source of contamination in aquatic ecosystems. In this study, we used 30-s kinetic bioassays based on $V$. fischeri to evaluate the toxicity associated to sediments from five localities with different contamination inputs (Morava River and its tributary Drevnice River in the south-eastern part of the Czech Republic). Toxicity

OPEN ACCESS

Edited by:

George Tsiamis,

University of Patras, Greece

Reviewed by:

Prasun Ray,

Samuel Roberts Noble Foundation,

USA

Christophe Leboulanger Institut de Recherche pour le Développement (IRD), France

*Correspondence: Ludek Bláha

blaha@recetox.muni.cz

Specialty section:

This article was submitted to

Systems Microbiology,

a section of the journal

Frontiers in Microbiology

Received: 12 July 2016 Accepted: 18 October 2016 Published: 07 November 2016

Citation:

Jarque S, Masner P, Klánová J,

Prokeš R and Bláha L (2016) Bioluminescent Vibrio fischeri Assays in the Assessment of Seasonal and

Spatial Patterns in Toxicity of

Contaminated River Sediments.

Front. Microbiol. 7:1738.

doi: 10.3389/fmicb.2016.01738 assessed as half maximal inhibitory concentration $\left(\mathrm{IC}_{50}\right)$ over the course of a year-long sampling was compared in bottom sediments and freshly trapped particulate material. Standard approach based on testing of aqueous elutriates was compared with toxicity of whole sediments (contact suspension toxicity). Bottom sediments showed lower toxicity compared to freshly trapped suspended materials in all cases. On the other hand, standardized elutriates induced generally weaker effects than suspended sediments likely due to losses during the extraction process. Toxicity generally increased during winter reaching maximum peaks in early spring months in all five sites. Total organic carbon (TOC) was found to be highly correlated with toxic effects. Toxicity from sites with direct industrial and agricultural water inputs also correlated with concentrations of metals, polycyclic aromatic hydrocarbons (PAHs), and polychlorinated biphenyls (PCBs). Single time point sampling followed by the extraction and testing of elutriates, do not truly reflect the spatial and temporal variability in natural sediments and may lead to underestimation of ecotoxic risks.

Keywords: sediment, Vibrio fischeri, toxicity, monitoring, seasonality

\section{INTRODUCTION}

Natural compounds and anthropogenic pollutants such as organic compounds, pesticides, and heavy metals released into the environment accumulate in ecosystems, notably freshwater bodies, and pose risk to endogenous organisms. The undesired effects range from alteration of natural microbial communities (Sheik et al., 2012) to physiological disorders in higher organisms. The first may lead to changes in the trophic levels, while the second may result in species reproductive impairment or even lethality (Gust, 2006; Ward et al., 2013). Therefore, it is crucial to detect potential signs of toxicity in the earliest stages when damages in aquatic ecosystems are presumably less harmful and reversible. At present, toxicity in water bodies, including rivers, can be evaluated by analyzing the structure and abundance of biological communities, by measuring concentrations 
of chemicals that can be related to contaminant bioavailability and adverse effects and/or by direct assessing of toxicity using bioassays. The first approach is typically time-consuming and expensive, while the chemical measurements can be hard to extrapolate into biological systems and may lead to misinterpretation. As a consequence, there is a current need for the development of simple and inexpensive bioassays for the rapid assessment of environmental risks including aquatic matrices.

Sediments constitute an important part of aquatic ecosystems (Wetzel, 2001). If water bodies contaminate, sediments serve as trap for toxicants and potential secondary source of contamination, for example after resuspension of particles (Eggleton and Thomas, 2004) or after application on soils as fertilizer (Smith et al., 2008). Although sediments are considered relatively stable compared to the water phase, spatial, and temporal variability in sediments have been reported in many studies (Hilscherová et al., 2010; Bednarova et al., 2013; Macikova et al., 2014). Population densities and related anthropogenic activities, both agricultural and industrial, affect seasonal, and temporal patterns of contamination in fluvial sediments (Grosbois et al., 2006). Moreover, several abiotic factors such as sediment composition and geochemical processes can also influence final concentrations of pollutants and their toxicity (Bláha et al., 2010; Hilscherová et al., 2010; Perrichon et al., 2014).

At present, there are several bioassays used as monitoring tool to assess toxicity in sediments. They include representatives from all trophic levels-algae as producers, invertebrates or vertebrates as consumers and bacteria in the role of decomposers (Ahlf et al., 2002; Tuikka et al., 2011; Giusto et al., 2014; Hafner et al., 2015). Among them, bacterial assays have become particulary popular because of being simple, fast and inexpensive, having good correlations with other toxicity assay responses (Parvez et al., 2006) including higher organisms (Kahru et al., 1996; Kaiser, 1998). Accordingly, bacteria bioluminescence inhibition tests represent usually the first choice to test toxicity in sediments. These tests are traditionally performed by studying extracts or aqueous elutriates (more suitable for aquatic assays) or directly exposing bacteria to contaminated matrices, i.e., contact tests (Brouwer et al., 1990). The contact testing procedures, however, may be affected by confounding factors such as bacteria adsorption on particle surfaces, presence of ammonia, sulfur or sulfides, physical interference of bioluminescence with color or particles or $\mathrm{pH}$ variations (Volpi Ghirardini et al., 2009). As a suitable alternative for testing of sediments kinetic bioassay with Vibrio fischeri (also known as Flash assay) has been suggested, which uses each sample as its own reference, so color correction is possible with minimal manipulation (Lappalainen et al., 2001; Bláha et al., 2010).

In the present study, we assessed the toxicity of sediment samples from five locations with different chemical inputs in the south-eastern part of the Czech Republic using $V$. fischeri bioluminescence Flash tests. The approach based on testing of aqueous elutriates was compared with toxicity of whole sediments (contact suspension toxicity). The toxicity was assessed in bottom sediments (longer-term accumulation of toxicants) and freshly trapped particulate material (recent contamination events), respectively. Seasonal variability in toxicity was evaluated throughout a complete year. The toxicity results were correlated with concentrations of traditionally studied environmental contaminants like metals, PAHs or organochlorine compounds.

\section{MATERIALS AND METHODS}

\section{Sediment Sampling Sites}

In total 150 samples, 75 from bottom sediments, and 75 from recent sediments or sediment traps were collected from five different sampling sites (Malenovice, Belov, Spytihnev, Certak, and Certak oxbow lake) in the Morava River and its tributary Drevnice River, both located in the south-eastern part of the Czech Republic (Figure 1). Samples were periodically collected every 28 days from June 2007 to July 2008, with 15 samplings throughout the season. Near to Zlín city, Malenovice locality is situated on the Drevnice River in an area with strong presence of industries in rubber, footwear and mechanical engineering. Belov site is located in an agricultural area and reflects the situation in Morava River upstream from the confluence with Drevnice River. Spytihnev locality is situated downstream and integrates the contamination from both Morava and Drevnice rivers. Certak and Certak oxbow lake are both located on Morava River. Certak represents the normal watercourse, while Certak oxbow lake is part of a channel that remained abandoned since 1930s, when new channel regulations were implemented.

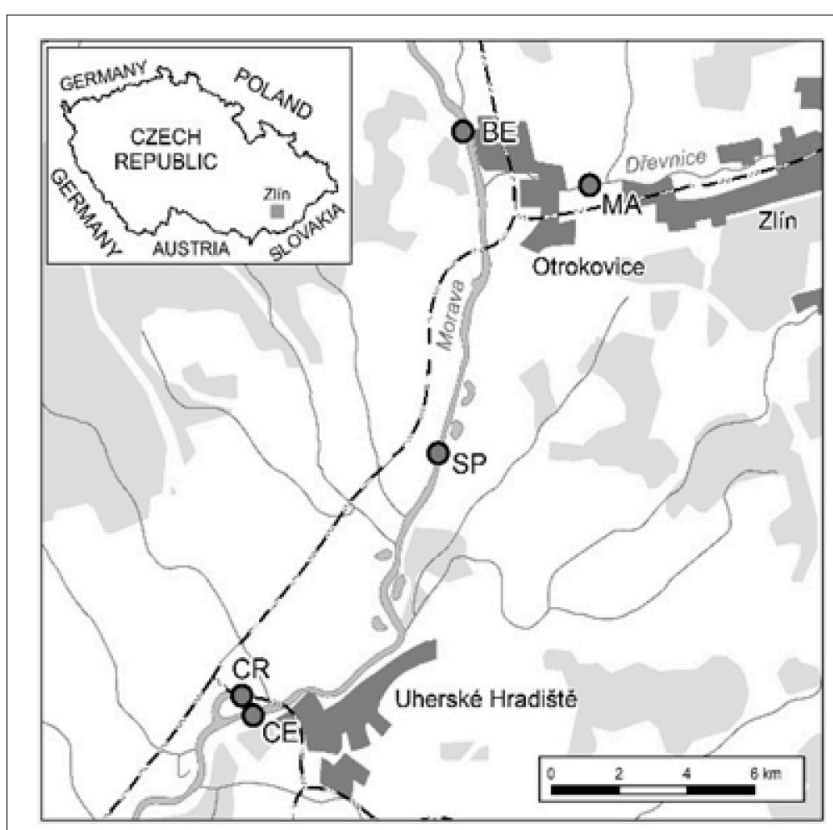

FIGURE 1 | Location of sampling sites within the studied area: MA, Malenovice (Drevnice River); BE, Belov (Morava River); SP, Spytihnev (Morava River); CE, Certak (Morava River); CR, Certak oxbow lake (Morava River). 


\section{Sample Collection}

Two types of samples, i.e., bottom sediments and fresh recent sedimented material were collected. Bottom sediments samples (top $0-10 \mathrm{~cm}$ layer) were collected using the plastic trowels. Recent sediments were taken using glass sediment traps placed close to the river bed but avoiding direct contact with bottom sediments. Unwanted debris such as large pieces of wood, leaves and stones were removed from all samples. The samples were then homogenized and subsequently freeze-dried (Gamma 1-16 LSC, Christ). Dry sediments were then sieved ( $2 \mathrm{~mm}$ mesh). Samples were clustered according to the four hydrological seasons, i.e., spring (March-May), summer (June-August), autumn (September-November), and winter (December-February), being October-March and AprilSeptember the colder and warmer seasons, respectively.

\section{Sediment Characteristics}

Sediment samples were characterized by measuring the content of total organic carbon (TOC) using high-temperature LiquiTOC II analyser (Elementar Analysensysteme). The grain size distribution was determined using a Retsch AS 200 sieving machine (Retsch, 0.036-4 mm fractions) and a Cilas 1064 laser diffraction granulometer (IVA Industrieberatung, 0.0004$0.5 \mathrm{~mm}$ fractions).

\section{Chemical Analyses of Organic Contaminants}

Freeze-dried sediments $(10 \mathrm{~g})$ were extracted with dichloromethane (DCM) using automated Büchi B-811 extractor (Büchi). The concentrated extracts were cleaned up on silica column (for PAHs) and $\mathrm{H}_{2} \mathrm{SO}_{4}$ modified silica column (organohalogens). Copper powder was used to remove sulfur. Samples were analyzed using GC-MS (Agilent $6890 \mathrm{~N}$ GC/Agilent 5973N MS) supplied with a J\&W Scientific fused silica column DB-5MS for 16 U.S. Environmental Protection Agency polycyclic aromatic hydrocarbons (PAHs), polychlorinated biphenyls (PCBs, congeners 28, 52, 101, 118, 138,153 , and 180), organochlorine pesticides (OCPs, namely $\alpha-, \beta-, \gamma$-, and $\delta$-isomers of hexachlorocyclohexane, $\mathrm{HCH}, \mathrm{p}, \mathrm{p}^{\prime}-$ dichlorodiphenyltrichloroethane, $\mathrm{p}, \mathrm{p}^{\prime}$-DDT, and metabolites $\mathrm{p}, \mathrm{p}^{\prime}-\mathrm{DDE}$ and $\mathrm{p}, \mathrm{p}^{\prime}$-DDD, and finally hexachlorobenzene, HCB). Concentrations of chemicals were quantified using Pesticide Mix 13 (Dr. Ehrenstorfer, GmbH) and PAH Mix 27 (Promochem) standard mixtures.

\section{Chemical Analyses of Metals}

Concentrations of metals that are known to be toxic and represent environmental hazards in waters and sediments $(\mathrm{V}$, $\mathrm{Cr}, \mathrm{Co}, \mathrm{Ni}, \mathrm{Cu}, \mathrm{Zn}, \mathrm{As}, \mathrm{Mo}, \mathrm{Cd}, \mathrm{Sb}, \mathrm{Pb}$, and $\mathrm{Hg}$ ) were determined according to ISO 11466 method adapted to analytical instrumentation. Nitro-hydrochloric acid $\left(2.3 \mathrm{ml} \mathrm{HNO}_{3}\right.$ and $7.0 \mathrm{ml} \mathrm{HCl}$ ) was used to leaching metals from sediments $(1 \mathrm{~g}$ dry weight). Analyses were performed with using ICP-MS on Agilent 7500ce instrument (Agilent). Mercury in samples was determined with a thermo-oxidation method using AMA-254 analyser (Altec).

\section{Bacterial Kinetic Luminescence Assay}

Kinetic bioassays were performed in microplates as previously described (Bláha et al., 2010), with minor modifications. Given that the flash protocol is compatible with colored sediment matrices, toxicity in sediment samples was tested by direct contact between $V$. fischeri and the solid phase (Lappalainen et al., 1999, 2001). Sediment suspensions and aqueous elutriates were prepared according to European Norm (EN 12920:2006+A1:2008).

Sediment suspensions (100 mg dry wt sed./ml of distilled water, $\mathrm{pH} 7.0 \pm 0.2$ ) were pre-prepared by shaking (vortex, 2000 $\mathrm{rpm}$ ) for $5 \mathrm{~min}$ and tested immediately or stored at $4^{\circ} \mathrm{C}$ for no more than $24 \mathrm{~h}$ before testing. Suspensions were then shaken once again (30 s) immediately before testing, and $0.15 \mathrm{ml}$ were pipetted into micro-plate wells along with $0.01 \mathrm{ml}$ of $32 \% \mathrm{w} / \mathrm{v}$ sodium chloride $(\mathrm{NaCl})$ to reach the final concentration of $2 \%$ $\mathrm{NaCl}$ necessary for marine $V$. fisheri. Serial dilutions (1:1) for each sample were directly prepared in $2 \% \mathrm{w} / \mathrm{v} \mathrm{NaCl}(\mathrm{pH} 7.0 \pm$ 0.2 ) in the microplate. Final concentrations tested (considering dilution with bacterial inoculum) were $75,37.5,18.75,9.38$, and $4.69 \mathrm{mg}$ dry wt sed./ml. Elutriates were prepared in microtubes with sediment suspensions (100 mg dry wt sed./ml) shaken at $15 \mathrm{rpm}$ for $24 \mathrm{~h}$ using a slow multi rotator. Suspensions were then centrifuged at $7000 \mathrm{rpm}$ for $10 \mathrm{~min}$ and supernatants were diluted as previously described (serial dilutions $1: 1$ in $2 \% \mathrm{NaCl}, 5$ concentrations).

Microplates containing sample aliquots $(0.08 \mathrm{ml}$ of serial dilutions of sediment suspensions or elutriate supernatants), positive controls $\left(\mathrm{K}_{2} \mathrm{Cr}_{2} \mathrm{O}_{7}, 380 \mathrm{mg} / \mathrm{ml}\right.$ of $\left.2 \% \mathrm{NaCl}\right)$ and negative controls $(2 \% \mathrm{w} / \mathrm{v} \mathrm{NaCl})$ were temperate at $15^{\circ} \mathrm{C}$ and toxicity tested as described below.

Freeze-dried luminescent bacteria $V$. fischeri NRRL B-11177 (Institute of Microbiology, Czech Academy of Sciences) were reconstituted according to ISO 11348-3 (1998) in ice-cold 2\% $\mathrm{w} / \mathrm{v} \mathrm{NaCl}$ and kept on ice. Prior to testing, aliquots of bacterial suspension were diluted in $2 \% \mathrm{NaCl}$ and tempered at $15^{\circ} \mathrm{C}$ in a water bath for $30 \mathrm{~min}$. $0.02 \mathrm{ml}$ of bacteria suspension were injected into each well of the microplates with studied samples, and the luminescence was immediately monitored for $2 \mathrm{~s}$ (initial peak value). The luminescence was measured using a microplate Luminoscan Ascent luminometer (Thermo) equipped with computer-controlled injectors. The microplate was then shaken inside the luminometer incubated at $15^{\circ} \mathrm{C}$ and the final toxicity signal recorded after $30 \mathrm{~s}$ (S30-value). The inhibition of luminescence (percentage of control) was calculated as follows:

$$
I N H \%=100-\frac{S 30}{C F \times P e a k} \times 100,
$$

where $C F$ is a correction factor (the $S 30 /$ peak ratio in negative controls) reflecting natural attenuation of bacterial luminescence during $30 \mathrm{~s}$ exposures.

Concentrations of sediment suspensions that caused $50 \%$ inhibition of luminescence $\left(\mathrm{IC}_{50}\right.$ in $\mathrm{mg}$ dry weight $/ \mathrm{ml}$ ) were derived from the four-parametric logistic curve calculated in Graph-Pad $^{\mathrm{TM}}$ Prism (GraphPad Software). Because sediment 
elutriates rarely caused $50 \%$ decreases in luminescence, the $\mathrm{IC}_{50}$ value was replaced in those cases by the $\mathrm{INH}_{75}$-value, which was defined as a decrease in the light emission observable after $30 \mathrm{~s}$ in a non-diluted aqueous extract corresponding to $75 \mathrm{mg} \mathrm{dw}$ sed./ml.

\section{Data Analyses}

Standard summary statistics were used to describe distributions of the primary data. Non-parametric analyses were applied, because assumptions of parametric analyses (normality of data distribution) were not found in all variants. Correlations between sediment parameters and toxicity were tested using Spearman's rank correlation, differences were tested by Wilcoxon paired test. For all of the tests, $p<0.05$ were considered statistically significant. Calculations were performed in Statistica (StatSoft, Tulsa, OK, USA).

To better visualize the results, the individual data points within each analyzed parameters (for chemical analyses results as well as toxicity) were categoried into four groups (I-IV). This approach allowed for better relative comparisons of different analyzed parameters, where the actual numerical values ranged across orders of magnitude. Group I represented the smallest levels of contamination (or the lowest toxicity, respectively), and the group IV contained the highest values of contamination or toxicity, respectively. The groups I-IV were formed as follows: the minimum (MIN0) and maximum (MAX0) of all detected values of a certain parameter were cut off to eliminate extremes. The values falling between the second minimal (MIN) and the second maximal $(M A X)$ values were then divided into four groups (I-IV) based on the statistical distributions. For each parameter (i.e., toxicity value, organic carbon-TOC, or concentrations of individual contaminants), the upper limits (L) for each of the 4 groups were calculated:

$$
L=M I N+a \cdot \frac{(M A X-M I N)}{4},
$$

where $a=1$ or 2 or 3 or 4 for Groups I-IV, respectively. Examples of criteria (limits, $L$ ) for groups I, II, III, and IV for selected parameters (TOC, sum of PAHs, total Cd concentrations) are shown in Supplementary Table S1.

\section{RESULTS}

Summary of the toxicity testing is shown in Table 1. Detailed results for all bottom and recent sediment samples are presented in Supplementary Table S2 (toxicity of suspended materials) and Supplementary Table S3 (the inhibitory effects observed in aquatic elutriates).

\section{Toxicity of Sediment Suspensions vs. Aqueous Elutriates}

In general, aquatic elutriates were significantly less toxic compared to the suspensions from the same sampling site. In elutriates the $50 \%$ inhibitory effects were observed only rarely, and the toxicity could be described only as inhibitions of luminescence (\%) at the highest tested concentration of sediment elutriate (corresponding to $75 \mathrm{mg} \mathrm{dw} / \mathrm{mL}$, Supplementary Table S3). Sediment suspensions showed in general more pronounced effects allowing for calculation of $\mathrm{IC}_{50}$ (Supplementary Table S2 and Table 1). However, the toxic responses of $V$. fisheri to elutriates and suspensions were significantly correlated (Spearman rank coefficient for all samples $N=121, R s=0.849$, $p<0.0001)$.

\section{Toxicities of Bottom Sediments vs. Fresh Sediment from Traps}

Detailed investigation of the toxicity results of suspended materials revealed that recent sediments from traps $\left(\mathrm{IC}_{50}\right.$ median values ranging from 7.8 to $53.7 \mathrm{mg}$ dry weight $/ \mathrm{ml}$ ) were generally more toxic than bottom sediments (IC50 23.6 to $>75 \mathrm{mg}$ dry weight $/ \mathrm{ml}$; Table 1). The difference was confirmed by Wilcoxon Matched Pairs Test $(N=47, Z=5.46, p<0.0001)$.

\section{Seasonal Variability in Toxicity Responses}

Toxicity of both bottom and freshly trapped sediments showed a clear seasonal pattern for all sampling sites (Table 1, Supplementary Table S2, Figure 2). The toxicity increased during the winter period and reached the lowest IC50-values at the end of February or beginning of March. Systematically lowest toxicity was detected during summer months.

\section{Spatial Variability in Toxicity}

With respect to bottom sediments, the lowest toxicity was systematically found at Certak and Certak oxbow lake, the two sites further downstream away from the city of Zlín (the highest IC50-values in Table 2 and Figure 3A). The pattern is also clear from Figure 4A-bottom sediments), where distributions of $1 /$ IC50 toxicity values are shown as pie charts. On the other hand relatively higher toxicities of bottom sediments were found at Malenovice and Belov sites. For fresh sediments from traps (Figures 3B, 4B), toxicity results did not show as apparent spatial differences between sites as for bottom sediments. The site with the highest toxicity was again Malenovice and interestingly, the second highest toxicities were found at Certak oxbox-lake.

\section{Contamination Results}

The complete results of analysis of total 17 different contaminant groups-five organic (sums of PAHs, PCBs, HCHs, DDTs, and $\mathrm{HCB}$ ) and 12 toxic metals in studied bottom and fresh sediments are shown in Supplementary Table S4 (EXCEL). To better visualize and compare the chemical loads, the values were transferred to relative groups I-IV as described in Materials and Methods Section, and the aggregate results per individual sites are shown in Figure 4A (bottom sediments) and Figure 4B (sediment traps). Bottom sediments were most polluted at Spytihnev site (almost $60 \%$ of the values were in the highest contamination Groups III or IV-cf Figure 4A-Spytihnev pie charts for contamination). Interestingly, the samples from this site did not elicit major toxic effects (cf Figure 4A-piecharts for $1 /$ IC50-values). On the contrary, the lowest levels of bottom sediment contamination were detected in Certak oxbow lake, and the findings corresponded to the pattern of toxicities 
TABLE 1 | Annual and seasonal toxicity $\left(\mathrm{IC}_{50}\right)$ levels obtained with the 30 -s kinetic Vibrio fischeri assay in bottom and recent sediments tested in suspensions.

\begin{tabular}{|c|c|c|c|c|c|c|}
\hline \multirow[t]{2}{*}{ Localityb } & \multirow[t]{2}{*}{$\mathrm{N}^{\mathrm{C}}$} & \multicolumn{5}{|c|}{ Toxicity $\left(\mathrm{IC}_{50}, \mathrm{mg} / \mathrm{ml}\right)^{\mathrm{a}}$} \\
\hline & & Spring & Summer & Autumn & Winter & All seasons \\
\hline \multirow{2}{*}{$\begin{array}{l}\text { Bottom } \\
\text { sediment }\end{array}$} & 73 & 53.6 & $>75.0$ & 63.2 & 55.8 & 63.8 \\
\hline & $(15+24+15+19)$ & $(12.4->75.0)$ & $(30.6->75.0)$ & $(36.5->75.0)$ & $(13.5->75.0)$ & $(12.4->75.0)$ \\
\hline \multirow[t]{2}{*}{ MA } & 15 & 39.4 & 71.0 & 60.6 & 23.6 & 43.8 \\
\hline & $(3+5+3+4)$ & $(12.4-74.1)$ & $(30.6->75.0)$ & $(36.5-65.0)$ & $(13.5-43.8)$ & $(12.4->75.0)$ \\
\hline \multirow[t]{2}{*}{$\mathrm{BE}$} & 14 & 27.9 & 72.5 & 41.9 & 34.4 & 46.1 \\
\hline & $(3+4+3+4)$ & $(20.1-34.9)$ & $(63.3->75.0)$ & $(37.6-54.3)$ & $(19.2-58.3)$ & $(19.2->75.0)$ \\
\hline \multirow[t]{2}{*}{$\mathrm{SP}$} & 14 & 53.6 & 60.5 & 62.1 & 73.9 & 60.9 \\
\hline & $(3+5+3+3)$ & $(38.5-58.3)$ & $(49.1-63.8)$ & $(61.2-63.2)$ & $(46.4->75.0)$ & $(38.5->75.0)$ \\
\hline \multirow[t]{2}{*}{ CE } & 15 & $>75.0$ & $>75.0$ & $>75.0$ & $>75.0$ & $>75.0$ \\
\hline & $(3+5+3+4)$ & $(>75.0->75.0)$ & $(>75.0->75.0)$ & $(70.3->75.0)$ & $(>75.0->75.0)$ & $(70.3->75.0)$ \\
\hline \multirow[t]{2}{*}{ CR } & 15 & 54.4 & $>75.0$ & $>75.0$ & 67.9 & $>75.0$ \\
\hline & $(3+5+3+4)$ & $(25.4->75.0)$ & $(>75.0->75.0)$ & $(>75.0->75.0)$ & $(48.0->75.0)$ & $(25.4->75.0)$ \\
\hline \multirow{2}{*}{$\begin{array}{l}\text { Recent (trap) } \\
\text { sediment }\end{array}$} & 49 & 26.0 & 43.5 & 29.6 & 21.2 & 28.4 \\
\hline & $(10+16+10+13)$ & $(4.6-53.7)$ & $(10.4-63.7)$ & $(18.0-75.8)$ & $(4.9->75.0)$ & $(4.6->75.0)$ \\
\hline \multirow[t]{2}{*}{ MA } & 12 & 7.8 & 38.2 & 22.3 & 8.1 & 15.7 \\
\hline & $(2+4+3+3)$ & $(4.6-11.0)$ & $(10.4-56.0)$ & $(20.3-37.7)$ & $(4.9-9.4)$ & $(4.6-56.0)$ \\
\hline \multirow[t]{2}{*}{$\mathrm{BE}$} & 9 & $30.8^{d}$ & 42.3 & 39.1 & 27.5 & 30.8 \\
\hline & $(1+3+2+3)$ & & $(41.9-42.5)$ & $(23.1-55.2)$ & $(21.2-27.6)$ & $(21.2-55.2)$ \\
\hline \multirow[t]{2}{*}{$\mathrm{SP}$} & 11 & 27.6 & 50.0 & 36.3 & $20.5^{\mathrm{d}}$ & 33.5 \\
\hline & $(3+4+3+1)$ & $(24.5-29.8)$ & $(33.5-63.0)$ & $(30.5-75.8)$ & & $(20.5-75.8)$ \\
\hline \multirow[t]{2}{*}{ CE } & 7 & $53.7^{d}$ & 54.5 & $28.8^{d}$ & 45.7 & 45.7 \\
\hline & $(1+2+1+3)$ & & $(45.4-63.7)$ & & $(21.7->75.0)$ & $(21.7->75.0)$ \\
\hline \multirow[t]{2}{*}{ CR } & 10 & 19.4 & 33.1 & $18.0^{\mathrm{d}}$ & 14.7 & 18.7 \\
\hline & $(3+3+1+3)$ & $(17.3-28.4)$ & $(16.9-48.8)$ & & $(14.2-22.9)$ & $(14.2-48.8)$ \\
\hline
\end{tabular}

${ }^{a}$ Values indicate concentrations causing $50 \%$ inhibition of bioluminescence after 30 -s exposures (mg sediment dry weight/ml). Expressed as median (min-max).

${ }^{b}$ MA, Malenovice; BE, Belov; SP, Spytihnev; CE, Certak; CR, Certak oxbow lake.

${ }^{c}$ Number of samples - total number and numbers from different seasons (Spring + Summer + Autumn + Winter).

dThe only detected value.

(cf Figure 4A). With regard to freshly trapped sediments (Figure 4B) no major differences were apparent among the sites in contaminant levels or toxicity (as apparent from the distribution patterns shown in pie-charts).

\section{Correlations between Toxicity and Contamination}

Correlation analyses between the toxicity values $\left(1 / \mathrm{IC}_{50}\right.$ for solid phase test and $\mathrm{INH}_{75}$ for elutriates) and 17 contaminant parameters and total organic carbon (TOC) are shown in Table 2 (bottom sediment samples) and Table 3 (sediment traps).

In bottom sediments (Table 2), 16 out of 18 variables correlated with the $\mathrm{IC}_{50}$-values from tests with solid phase suspensions when considering data from all sites $(N=75)$. The toxicity of elutriates (INH75-values) correlated with only eight parameters. In the sediments from Malenovice and Belov (where the toxicity values were variable and widely distributed-cf Figure 2A) the highest number of significant correlations was observed for both 1/IC50 and INH75 (especially between the toxicity and metal concentrations, Table 2). Only rare correlations were detected at the other sites. For recent sediments from traps (Table 3), generally lower number of significant correlations between toxicity and matrix composition was recorded. Correlations in samples from Malenovice site highlighted links to concentrations of PAHs, PCBs, HCB, and some metals.

Further, principal component analysis (PCA) defined two principal factors that explained the 70 and $59.6 \%$ of the total observed variability in bottom sediments and trap samples, respectively (Figure 5). Toxicity in bottom sediments appeared to be intimately related to TOC, although close associations were also found for HCB and PAHs. Heavy metals seemed to not contribute to the toxic activity. The relationship between toxicity and TOC was also apparent in sediment traps, but this association was slightly less pronounced compared to bottom sediments. Persistent pollutants such as PCBs, DDT, and $\mathrm{HCH}$ seemed to also contribute to toxicity. Similar to bottom sediments, toxicity seemed not to be related to the presence of metals. 

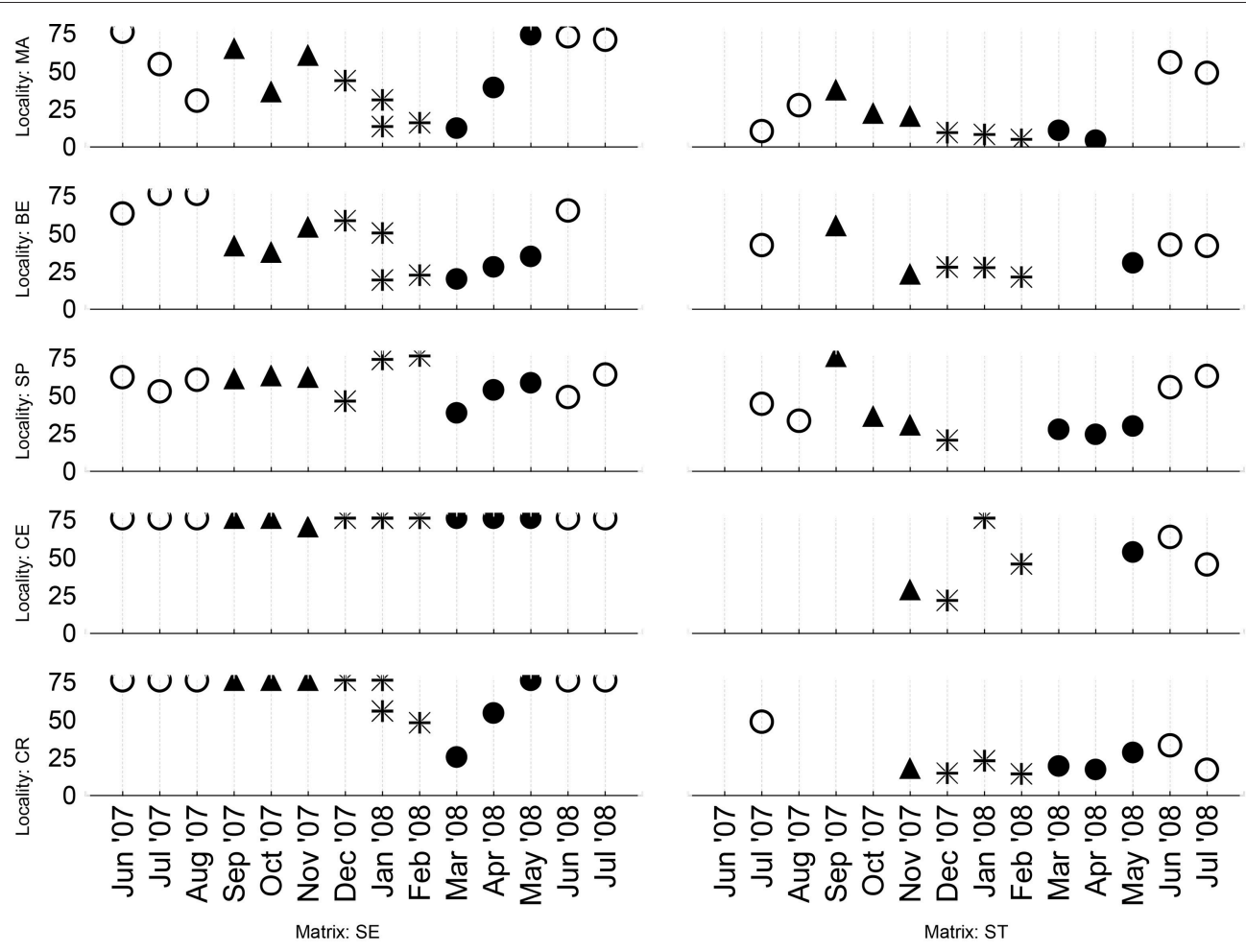

FIGURE 2 | Seasonal toxicity in samples of bottom sediment (SE-left graphs) and samples from sediment traps (ST) at given sampling sites/localities (MA, Malenovice; BE, Belov; SP, Spytihnev; CE, Certak; CR, Certak oxbow lake). The toxicity (expressed as 50\% inhibition concentration, IC50, in mg dry wt sediment/ml) is pictured vertically, whereas the horizontal axis shows the date of sampling (N.B. two samplings were carried out in January-on the 2nd and 30th).

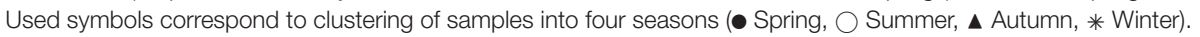
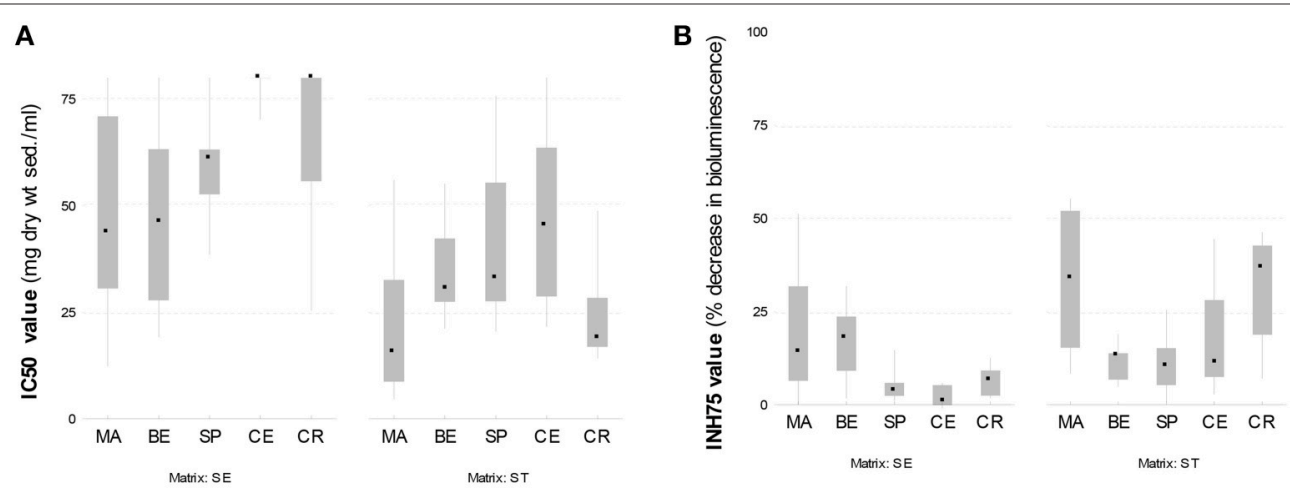

FIGURE 3 | Spatial distribution of toxicity-IC50-values from contact testing (A) and INH75-values from elutriate testing (B)-in bottom sediment (SE) and recent sediment (ST). MA, Malenovice; BE, Belov; SP, Spytihnev; CE, Certak; CR, Certak oxbow lake.

\section{DISCUSSION}

V. fischeri kinetic tests were successfully applied to assess toxicity in sediment suspensions and aqueous elutriates from five different sites in the Morava river basin, Czech Republic, which is a representative model ecosystem for mid-size industrial cities in central Europe. Although toxicity values for both approaches (suspension test vs. elutriate) showed a good correlation, toxicity in elutriates was significantly lower.
This is in line with previous studies that described reduced toxicities of the extracts (compared to whole sediments) due to the absence of particle-bounded toxicants and poor extraction of nonpolar compounds such as PCBs and PAHs (Ho and Quinn, 1993; Harkey et al., 1994; Guzzella, 1998). For this reason, testing of bacterial toxicity of elutriates can be recommended for water-soluble compounds rather than to reflect the total toxicity of bulk sediment (Ankley et al., 1991). 
TABLE 2 | Correlation between the toxicity (expressed as 1/C50 for solid phase test and INH75 for elutriate test-both tested with the 30-s kinetic Vibrio fischeri assay) and selected sediment parameters and concentrations of contaminants in bottom sediment (SE).

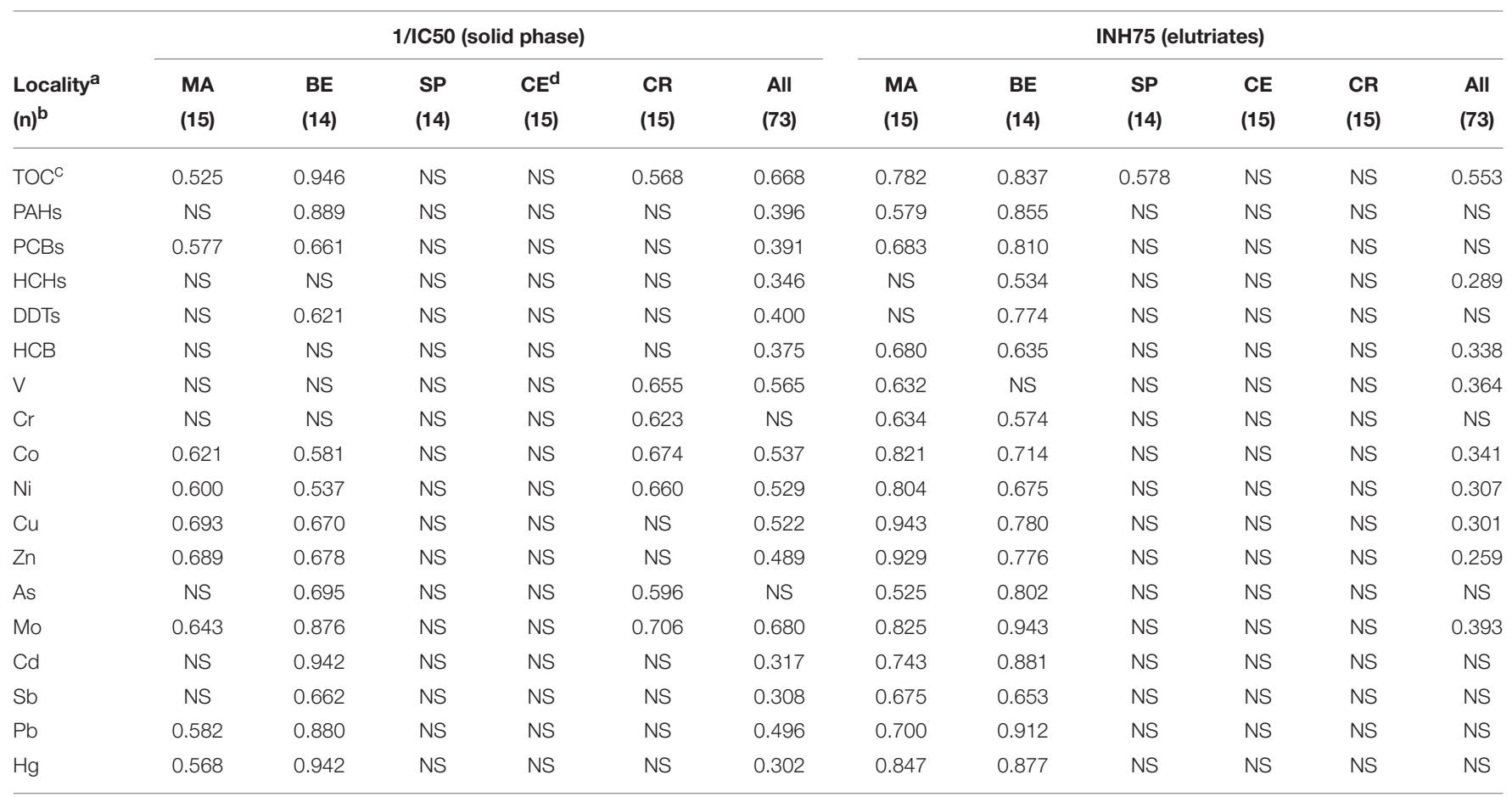

${ }^{a}$ MA, Malenovice; BE, Belov; SP, Spytihnev; CE, Certak; CR, Certak oxbow lake; All, all sampling sites.

${ }^{b}$ Number of paired values for correlation.

${ }^{C}$ TOC, total organic carbon (\%); PAHs, sum of polycyclic aromatic hydrocarbons (ng/g); PCBs, sum of polychlorinated biphenyls (ng/g); HCHs, hexachlorocyclohexane (all congeners,

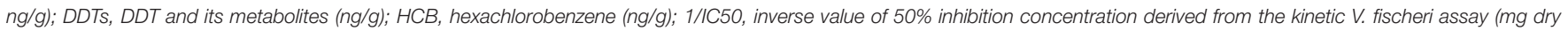
$w t / m l)$; INH75, decrease in light emission caused by $75 \mathrm{mg}$ dry wt sediment in test with elutriates (\%).

${ }^{d}$ Correlation is not possible here, because all toxicity values were $>75 \mathrm{mg}$ dry $\mathrm{wt} / \mathrm{ml}$.

$R$-values of Spearman rank correlation that were statistically significant $(P<0.05)$ are shown. (NS, no significant correlation).

Compared to bottom sediments, recently collected (trap) sediments showed nearly always (91.5\% of all samples) higher toxicity at all sampling sites, but no significant differences were observed among locations. On the contrary, bottom sediments generally showed higher toxicity at upstream sites located in a closer proximity to direct contamination sources. This is in agreement with recent studies of marine sediments, where different toxicity profiles were found between coastal/estuarine sediments and offshore sediments (Vethaak et al., in press). Interestingly, the most contaminated sites not always showed the highest toxicity in Vibrio assays. For instance, sediments from Spytihnev were highly contaminated compared to the rest of locations, while toxicity ranked among the lowest. This no linear correlation between chemical burden and toxicity has been described in several studies and points out to additional factors as toxicity drivers. In this sense, differences in bacterial toxicity may be related to the particular composition of the sediment and the different chemical association to sediment particles (Elzerman and Coates, 1987; Baker et al., 1991). It is wellknown that hydrophobic pollutants present different sorption behavior on silt and lime fractions, which determines their physical movement, bioavailability, persistence, and degradation, and that the differences in sorption depend largely on the amount of total organic carbon within each fraction (Karickhoff et al.,
1979). For instance, strong positive relationships between TOC and PAHs (Guo et al., 2009), metals (Chakraborty et al., 2014), and PCBs content (Ayris and Harrad, 1999; Backe et al., 2004) have been previously reported in sediments. Similarly, our results reflect a good correlation between TOC and the observed toxicity in the most toxic sites, pointing out TOC as a major candidate as toxicity driver. However, a linear relationship between TOC and chemical burden, e.g., organochlorine pesticides, is not always apparent (Parween et al., 2014), and therefore other sediment characteristics such as exchangeable $\mathrm{H}+$ or sulfur content could play an important role in the final sediment effect toxicity detected in our sediment samples (Hilscherova et al., 2007; Hilscherová et al., 2010). To our knowledge there are no evidences or studies indicating direct cytotoxic effects of TOC. However, major components of TOC such as humic acids have previously been shown to interfere with more subtle biological endpoints such as intracellular receptors in eukaryotic cells (Bittner et al., 2006; Janošek et al., 2007). Therefore, the relevance of biological effects of TOC and their eventual toxic outcomes should further be investigated.

POPs content in Morava river sediments was recently characterized (Prokeš et al., 2014; Supplementary Table S4). Similar to other rivers in Central Europe, PAHs are the dominant group of contaminants in the area (Müller et al., 2002). In 


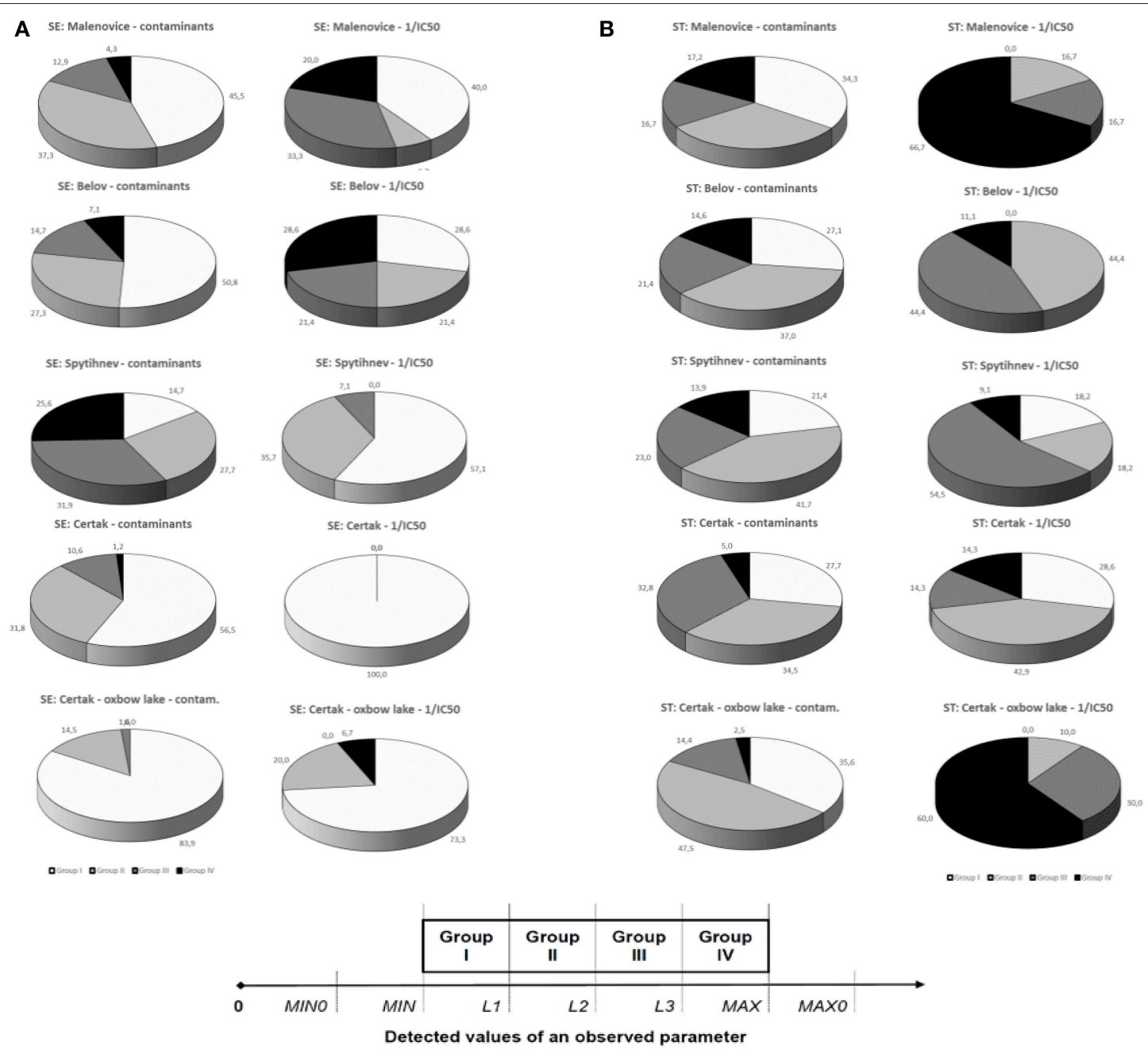

FIGURE 4 | Comparison of relative contamination (a collation for 17 groups of chemical classes) of bottom (SE, part A) and recent (ST, part B) sediment and relative toxicity detected with 30-s kinetic Vibrio fischeri assay. Group I (white sector) represents the lowest degree of contamination/toxicity, Group IV (black sector) the highest one. Numbers express a percentage of all values in given group. Criteria for grouping of detected values for each contaminant are described in Section Materials and Methods in more detail. Scheme of relative contamination clustering: MINO, the minimal value from all detected values; MIN, the second minimal value from all detected values; L1, the upper limit for the 1st group; L2, the upper limit for the 2nd group; L3, the upper limit for the 3rd group; MAX, the second maximal value from all detected values; MAXO, the maximal value from all detected values.

contrast, concentrations of heavy metals are rather low to moderate with only few local exceptions (Bednarova et al., 2013, this study). Organochlorine pesticides and PCBs seem to present a more diffusive contamination probably reflecting a longrange transport contamination rather than local emissions. In fully agreement, results obtained from PCA disclosed important contributions in the overall toxicity for $\mathrm{HCB}$ and $\mathrm{PAH}$ in bottom sediments, and PCBs, DDT, and $\mathrm{HCH}$ in sediment traps. On the contrary, heavy metals appeared to have a negligible role. Taking all together, PAHs are the compounds more likely to induce toxicity in our studied samples. Consistent with our hypothesis, lower chlorinated PCBs and lighter PAHs have been described to rapidly removed from surface waters and settle through the water column to the sediment water interface, easily mixing back into the water column. Conversely, PAHs with high molecular weights settle more slowly, getting buried in the sediments and not mixing with waters (Baker et al., 1991).

Toxicity in sediments followed seasonal patterns in all cases, increasing during winter, reaching its toxic peak in spring and decreasing in summer. Various biotic and abiotic factors such as human activities, temperature, rainfall, or drought may contribute to modulate, either positively or negatively, this temporal toxic effect (Müller et al., 2002; Stachel et al., 2005; Rosado et al., 2016). However, recent studies in POPs content and annual dynamics in this area pointed out the water flow as one of the major potential causes to explain the observed seasonal variation (Prokeš et al., 2014). Chemical concentrations in sediments would be modulated by episodic high flow events provoking the erosion of contaminant-containing particles. This would result in (i) resuspension of chemicals and thus increase 
TABLE 3 | Correlation between the toxicity (expressed as 1/C50 for solid phase test and INH75 for elutriate test-both tested with the 30 -s kinetic Vibrio fischeri assay) and selected sediment parameters and concentrations of contaminants in recent sediment (ST).

\begin{tabular}{|c|c|c|c|c|c|c|c|c|c|c|c|c|}
\hline \multirow[b]{2}{*}{$\begin{array}{l}\text { Localitya } \\
(n)^{b}\end{array}$} & \multicolumn{6}{|c|}{ 1/IC50 (solid phase) } & \multicolumn{6}{|c|}{ INH75 (elutriates) } \\
\hline & $\begin{array}{l}\text { MA } \\
\text { (12) }\end{array}$ & $\begin{array}{l}\text { BE } \\
\text { (9) }\end{array}$ & $\begin{array}{c}S P \\
(11)\end{array}$ & $\begin{array}{l}\text { CE } \\
(7)\end{array}$ & $\begin{array}{c}\text { CR } \\
\text { (10) }\end{array}$ & $\begin{array}{c}\text { All } \\
\text { (49) }\end{array}$ & $\begin{array}{l}\text { MA } \\
\text { (12) }\end{array}$ & $\begin{array}{l}\text { BE } \\
(9)\end{array}$ & $\begin{array}{c}S P \\
(11)\end{array}$ & $\begin{array}{l}\text { CE } \\
(7)\end{array}$ & $\begin{array}{l}\text { CR } \\
\text { (10) }\end{array}$ & $\begin{array}{c}\text { All } \\
\text { (49) }\end{array}$ \\
\hline $\mathrm{TOC}^{\mathrm{C}}$ & 0.858 & NS & 0.764 & NS & NS & 0.643 & 0.869 & 0.717 & 0.800 & 0.793 & NS & 0.614 \\
\hline $\mathrm{PAHs}$ & 0.776 & NS & NS & NS & NS & NS & 0.727 & NS & 0.618 & NS & NS & 0.294 \\
\hline PCBs & 0.783 & 0.933 & NS & 0.899 & NS & 0.607 & 0.825 & 0.883 & NS & NS & NS & 0.664 \\
\hline $\mathrm{HCHs}$ & NS & NS & NS & 0.943 & NS & NS & NS & NS & NS & 0.928 & NS & NS \\
\hline DDTs & NS & NS & NS & 0.829 & NS & NS & NS & NS & -0.690 & NS & NS & NS \\
\hline $\mathrm{HCB}$ & 0.603 & 0.750 & NS & 0.886 & NS & NS & 0.667 & NS & NS & 0.841 & NS & NS \\
\hline V & NS & NS & NS & NS & NS & NS & NS & NS & NS & NS & NS & -0.407 \\
\hline $\mathrm{Cr}$ & NS & NS & NS & NS & -0.636 & -0.389 & NS & NS & -0.664 & NS & -0.636 & -0.514 \\
\hline Co & NS & NS & NS & 0.893 & NS & NS & 0.620 & NS & NS & 0.829 & NS & NS \\
\hline $\mathrm{Ni}$ & 0.622 & NS & NS & 0.893 & NS & NS & 0.825 & NS & NS & 0.829 & NS & NS \\
\hline $\mathrm{Cu}$ & 0.790 & NS & NS & 0.821 & NS & 0.531 & 0.902 & 0.683 & NS & NS & NS & 0.405 \\
\hline $\mathrm{Zn}$ & 0.671 & 0.733 & 0.636 & 0.929 & NS & 0.604 & 0.699 & 0.850 & NS & 0.901 & NS & 0.487 \\
\hline As & NS & NS & NS & NS & NS & -0.373 & NS & NS & NS & NS & NS & -0.535 \\
\hline Mo & 0.895 & NS & NS & NS & NS & 0.303 & 0.874 & 0.667 & 0.791 & NS & NS & NS \\
\hline $\mathrm{Cd}$ & 0.692 & 0.800 & NS & NS & NS & NS & 0.671 & 0.933 & NS & 0.883 & NS & NS \\
\hline $\mathrm{Sb}$ & 0.685 & NS & NS & NS & NS & NS & 0.629 & NS & NS & NS & NS & NS \\
\hline $\mathrm{Pb}$ & 0.664 & 0.817 & NS & NS & NS & NS & 0.671 & 0.683 & NS & NS & NS & NS \\
\hline $\mathrm{Hg}$ & 0.629 & NS & NS & NS & NS & 0.345 & 0.643 & NS & NS & NS & NS & NS \\
\hline
\end{tabular}

${ }^{a}$ MA, Malenovice; BE, Belov; SP, Spytihnev; CE, Certak; CR, Certak oxbow lake; All, all sampling sites.

${ }^{b}$ Number of paired values for correlation.

CTOC, total organic carbon (\%); PAHs, sum of polycyclic aromatic hydrocarbons (ng/g); PCBs, sum of polychlorinated biphenyls (ng/g); HCHs, hexachlorocyclohexane (all congeners,

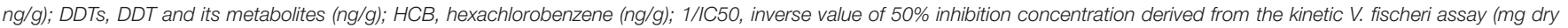
$w t / m l) ; ~ I N H 75$, decrease in light emission caused by $75 \mathrm{mg}$ dry wt sediment in test with elutriates (\%).

$R$-values of Spearman rank correlation (NS, no significant correlation).
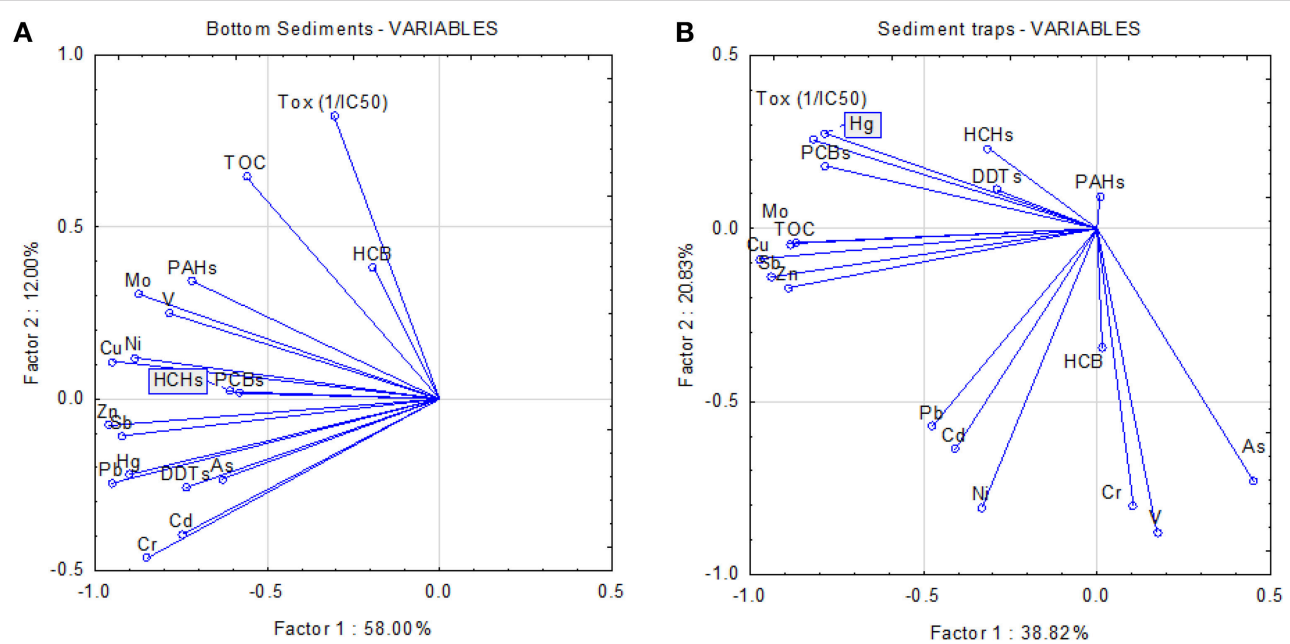

FIGURE 5 | Results of the principal component analysis (PCA) represented as score plots for factor 1 and factor 2 for bottom sediments (panel A) and fresh material from sediment traps (B). The 18 parameters [toxicity (Tox (1/IC50)) and chemical compounds] are shown as variables.

of their bioavailability, particularly in recent sediments, and (ii) movement of certain chemicals from sources to downstream sites. Both processes would increase toxicity associated to those chemicals, notably PAHs (Stachel et al., 2005; Bláha et al.,
2010; Prokeš et al., 2014). In addition, TOC in sediments typically increases during springtime. Sediments with higher concentrations of TOC have a larger sorption capacity for hydrophobic chemicals, which affects bioavailability of these 
pollutants. $V$. fischeri kinetic assays were able to reflect these temporal changes, highlighting the importance of periodical biological (effect-based) monitoring to avoid misinterpretation associated to specific time points.

\section{CONCLUSIONS}

The $V$. fischeri kinetic assay was proved to be a suitable tool for the assessment of toxicity in solid and colorful samples such as fluvial sediments. The study confirmed the good correlation between the $V$. fischeri kinetic assay performed directly in sediments (contact test) and the toxicity values obtained in elutriates. Our study demonstrated higher toxicity in samples from sediment traps in comparison to samples from bottom sediment collected at the same locality in the same time. In full agreement with previous hydrodynamics-based studies in the same area (Prokeš et al., 2014), toxicity showed clear seasonal patterns, typically increasing during winter and decreasing in summer, which highlights the importance of monitoring throughout the year rather than specific time points. Given the high concentrations of PAHs, the most dominant group of pollutants in the area, and the good correlation with both toxicity and TOC, PAHs seem to be the primary cause of toxicity. However, moderate contribution of other compounds such as organochlorine pesticides or metals (or other not analyzed contaminants) cannot be ruled out. Although the lack

\section{REFERENCES}

Ahlf, W., Hollert, H., Neumann-Hensel, H., and Ricking, M. (2002). A guidance for the assessment and evaluation of sediment quality a German Approach based on ecotoxicological and chemical measurements. J. Soils Sediments 2, 37-42. doi: 10.1007/BF02991249

Ankley, G. T., Schubauer-Berigan, M. K., and Dierkes, J. R. (1991). Predicting the toxicity of bulk sediments to aquatic organisms with aqueous test fractions: pore water vs. elutriate. Environ.Toxicol. Chem. 10, 1359-1366. doi: $10.1002 /$ etc. 5620101015

Ayris, S., and Harrad, S. (1999). The fate and persistence of polychlorinated biphenyls in soil. J. Environ. Monit. 1, 395-401. doi: 10.1039/a903017d

Backe, C., Cousins, I. T., and Larsson, P. (2004). PCB in soils and estimated soilair exchange fluxes of selected PCB congeners in the south of Sweden. Environ. Pollut. 128, 59-72. doi: 10.1016/j.envpol.2003.08.038

Baker, J. E., Eisenreich, S. J., and Eadie, B. J. (1991). Sediment trap fluxes and benthic recycling of organic carbon, polycyclic aromatic hydrocarbons, and polychlorobiphenyl congeners in Lake Superior. Environ. Sci. Technol. 25, 500-509. doi: 10.1021/es00015a019

Bednarova, Z., Kuta, J., Kohut, L., Machat, J., Klanova, J., Holoubek, I., et al. (2013). Spatial patterns and temporal changes of heavy metal distributions in river sediments in a region with multiple pollution sources. J. Soils Sediments 13, 1257-1269. doi: 10.1007/s11368-013-0706-2

Bittner, M., Janošek, J., Hilscherová, K., Giesy, J., Holoubek, I., and Bláha, L. (2006). Activation of Ah receptor by pure humic acids. Environ. Toxicol. 21, 338-342. doi: 10.1002/tox.20185

Bláha, L., Hilscherová, K., Cáp, T., Klánová, J., Machát, J., Zeman, J., et al. (2010). Kinetic bacterial bioluminescence assay for contact sediment toxicity testing: relationships with the matrix composition and contamination. Environ. Toxicol. Chem. 29, 507-514. doi: 10.1002/etc.81

Brouwer, H., Murphy, T., and McArdle, L. (1990). A sediment-contact bioassay with Photobacterium phosphoreum. Environ. Toxicol. Chem. 9, 1353-1358. doi: 10.1897/1552-8618(1990)9[1353:ASBWPP]2.0.CO;2 of standardized safety guidelines may limit the applicability of $V$. fischeri kinetic assays in sediments, some guidance values for acute toxicity have been recently suggested (Bláha et al., 2010) promoting thus further use of effect-based monitoring of environmental quality.

\section{AUTHOR CONTRIBUTIONS}

LB coordinated the research; LB and JK designed the study; PM, JK, RP performed research and analyzed data; SJ integrated and interpreted the results and wrote the paper, all coauthors contributed to paper finalization.

\section{ACKNOWLEDGMENTS}

Supported by the Czech Republic Ministry of Education, Youth and Sports infrastructure projects No. LO1214 and CETOCOEN UPgrade CZ.1.05/2.1.00/19.0382. The authors acknowledge technical support from undergraduate students Tomáš Čáp and Zbyněk Šplíchal.

\section{SUPPLEMENTARY MATERIAL}

The Supplementary Material for this article can be found online at: http://journal.frontiersin.org/article/10.3389/fmicb. 2016.01738/full\#supplementary-material
Chakraborty, P., Sharma, B., Babu, P. V. R., Yao, K. M., and Jaychandran, S. (2014). Impact of total organic carbon (in sediments) and dissolved organic carbon (in overlying water column) on $\mathrm{Hg}$ sequestration by coastal sediments from the central east coast of India. Mar. Pollut. Bull. 79, 342-347. doi: 10.1016/j.marpolbul.2013.11.028

Eggleton, J., and Thomas, K. V. (2004). A review of factors affecting the release and bioavailability of contaminants during sediment disturbance events. Environ. Int. 30, 973-980. doi: 10.1016/j.envint.2004.03.001

Elzerman, A. W., and Coates, J. T. (1987). "Hydrophobic organic compounds on sediments: equilibria and kinetics of sorption", in Sources and Fates of Aquatic Pollutants, Advances Chemistry Series 216, Vol. 10, eds R. A. Hites and S. J. Eisenreich (Washington, DC: American Chemical Society), 263-317. doi: 10.1021/ba-1987-0216.ch010

Giusto, A., Salibián, A., and Ferrari, L. (2014). Biomonitoring toxicity of natural sediments using juvenile Hyalella curvispina (Amphipoda) as test species: evaluation of early effect endpoints. Ecotoxicology 23, 293-303. doi: 10.1007/s10646-013-1173-7

Grosbois, C., Meybeck, M., Horowitz, A., and Ficht, A. (2006). The spatial and temporal trends of $\mathrm{Cd}, \mathrm{Cu}, \mathrm{Hg}, \mathrm{Pb}$ and $\mathrm{Zn}$ in Seine River floodplain deposits (1994-2000). Sci. Total Environ. 356, 22-37. doi: 10.1016/j.scitotenv.2005.01.049

Guo, W., He, M., Yang, Z., Lin, C., Quan, X., and Men, B. (2009). Distribution, partitioning and sources of polycyclic aromatic hydrocarbons in Daliao River water system in dry season, China. J. Hazard. Mater. 164, 1379-1385. doi: 10.1016/j.jhazmat.2008.09.083

Gust, K. A. (2006). Joint toxicity of cadmium and phenanthrene in the freshwater amphipod Hyalella azteca. Arch. Environ. Contam. Toxicol. 50, 7-13. doi: 10.1007/s00244-004-4163-1

Guzzella, L. (1998). Comparison of test procedures for sediment toxicity evaluation with Vibrio fischeri bacteria. Chemosphere 37, 2895-2909. doi: 10.1016/S00456535(98)00331-2

Hafner, C., Gartiser, S., Garcia-Käufer, M., Schiwy, S., Hercher, C., Meyer, W., et al. (2015). Investigations on sediment toxicity of German rivers applying a 
standardized bioassay battery. Environ. Sci. Pollut. Res. Int. 22, 16358-16370. doi: 10.1007/s11356-015-4482-y

Harkey, G. A., Landrum, P. F., and Klaine S. J. (1994). Comparison of wholesediment, elutriate and pore-water exposures for use in assessing sedimentassociated organic contaminants in bioassays. Environ. Toxicol. Chem. 13, 1315-1329. doi: 10.1002/etc.5620130814

Hilscherová, K., Dusek, L., Sídlová, T., Jálová, V., Cupr, P., Giesy, J. P., et al. (2010). Seasonally and regionally determined indication potential of bioassays in contaminated river sediments. Environ. Toxicol. Chem. 29, 522-534. doi: $10.1002 /$ etc. 83

Hilscherova, K., Dusek, L., Kubik, V., Cupr, P., Hofman, J., Klanova, J., et al. (2007). Redistribution of organic pollutants in river sediments and alluvial soils related to major floods. J. Soils Sediments 7, 167-177. doi: 10.1065/jss2007.04.222

Ho, K. T. Y., and Quinn, J. G. (1993). Physical and chemical parameters of sediment extraction and fractionation that influence toxicity, as evaluated by microtox ${ }^{\circledR}$. Environ. Toxicol. Chem. 12, 615-625. doi: 10.1002/etc.5620120403

Janošek, J., Bittner, M., Hilscherová, K., Bláha, L., Giesy, J. P., and Holoubek, I. (2007). AhR-mediated and antiestrogenic activity of humic substances. Chemosphere 67, 1096-1101. doi: 10.1016/j.chemosphere.2006.11.045

Kahru, A., Tomson, K., Pall, T., and Kulm, I. (1996). Study of toxicity of pesticides using luminescent bacteria. Water Sci. Technol. 33, 147-154. doi: 10.1016/02731223(96)00292-2

Kaiser, K. L. (1998). Correlations of Vibrio fischeri bacteria test data with bioassay data for other organisms. Environ. Health Perspect. 106(Suppl.), 583-591. doi: 10.1289/ehp.98106583

Karickhoff, S., Brown, D., and Scott, T. (1979). Sorption of hydrophobic pollutants on natural sediments. Water Res. 13, 241-248. doi: 10.1016/00431354(79)90201-X

Lappalainen, J., Juvonen, R., Nurmi, J., and Karp, M. (2001). Automated color correction method for Vibrio fischeri toxicity test. Comparison of standard and kinetic assays. Chemosphere 45, 635-641. doi: 10.1016/S0045-6535(00) 00579-8

Lappalainen, J., Juvonen, R., Vaajasaari, K., and Karp, M. (1999). A new flash method for measuring the toxicity of solid and colored samples. Chemosphere 38, 1069-1083. doi: 10.1016/S0045-6535(98)00352-X

Macikova, P., Kalabova, T., Klanova, J., Kukucka, P., Giesy, J. P., and Hilscherova, K. (2014). Longer-term and short-term variability in pollution of fluvial sediments by dioxin-like and endocrine disruptive compounds. Environ. Sci. Pollut. Res. Int. 21, 5007-5022. doi: 10.1007/s11356-0132429-8

Müller, A., Heininger, P., Wessels, M., Pelzer, J., Grünwald, K., Pfitzner, S., et al. (2002). Contaminant levels and ecotoxicological effects in sediments of the river odra. Acta Hydrochim. Hydrobiol. 30, 244-255. doi: 10.1002/aheh.2003 90006

Parvez, S., Venkataraman, C., and Mukherji, S. (2006). A review on advantages of implementing luminescence inhibition test (Vibrio fischeri) for acute toxicity prediction of chemicals. Environ. Int. 32, 265-268. doi: 10.1016/j.envint.2005.08.022

Parween, M., Ramanathan, A., Khillare, P. S., and Raju, N. J. (2014). Persistence, variance and toxic levels of organochlorine pesticides in fluvial sediments and the role of black carbon in their retention. Environ. Sci. Pollut. Res. 21, 6525-6546. doi: 10.1007/s11356-014-2531-6
Perrichon, P., Le Bihanic, F., Bustamante, P., Le Menach, K., Budzinski, H., Cachot, J., et al. (2014). Influence of sediment composition on PAH toxicity using zebrafish (Danio rerio) and Japanese medaka (Oryzias latipes) embryo-larval assays. Environ. Sci. Pollut. Res. Int. 21, 13703-13719. doi: 10.1007/s11356-0143502-7

Prokeš, R., Vrana, B., Komprdová, K., and Klánová, J. (2014). Annual dynamics of persistent organic pollutants in various aquatic matrices: a case study in the Morava River in Zlín district, Czech Republic. J. Soils Sediments 14, 1738-1752. doi: 10.1007/s11368-014-0931-3

Rosado, D., Usero, J., and Morillo, J. (2016). Assessment of heavy metals bioavailability and toxicity toward Vibrio fischeri in sediment of the Huelva estuary. Chemosphere 153, 10-17. doi: 10.1016/j.chemosphere.2016.03.040

Sheik, C. S., Mitchell, T. W., Rizvi, F. Z., Rehman, Y., Faisal, M., Hasnain, S., et al. (2012). Exposure of soil microbial communities to chromium and arsenic alters their diversity and structure. PLOS ONE 7:e40059. doi: 10.1371/journal.pone.0040059

Smith, K. E., Schwab, A. P., and Banks, M. K. (2008). Dissipation of PAHs in saturated, dredged sediments: a field trial. Chemosphere 72, 1614-1619. doi: 10.1016/j.chemosphere.2008.03.020

Stachel, B., Jantzen, E., Knoth, W., Krüger, F., Lepom, P., Oetken, M., et al. (2005). The Elbe flood in August 2002-organic contaminants in sediment samples taken after the flood event. J. Environ. Sci. Health. A. Tox. Hazard. Subst. Environ. Eng. 40, 265-87. [Accessed March 14, 2016]. doi: 10.1081/ESE200045531

Tuikka, A. I., Schmitt, C., Höss, S., Bandow, N., von der Ohe, P. C., de Zwart, D., et al. (2011). Toxicity assessment of sediments from three European river basins using a sediment contact test battery. Ecotoxicol. Environ. Saf. 74, 123-131. doi: 10.1016/j.ecoenv.2010.08.038

Vethaak, A. D., Hamers, T., Martínez-Gòmez, C., Kamstra, J. H., de Weert, J., Leonards, P. E. G., et al. (in press). Toxicity profiling of marine surface sediments: a case study using rapid screening bioassays of exhaustive total extracts, elutriates and passive sampler extracts. Mar. Environ. Res. doi: 10.1016/j.marenvres.2016.03.002

Volpi Ghirardini, A., Girardini, M., Marchetto, D., and Pantani, C. (2009). Microtox solid phase test: effect of diluent used in toxicity test. Ecotoxicol. Environ. Saf. 72, 851-861. doi: 10.1016/j.ecoenv.2008.01.011

Ward, D. J., Simpson, S. L., and Jolley, D. F. (2013). Slow avoidance response to contaminated sediments elicits sublethal toxicity to benthic invertebrates. Environ. Sci. Technol. 47, 5947-5953. doi: 10.1021/es400152a

Wetzel, R. G. (2001). Limnology: Lake and River Ecosystems, 3rd Edn. San Diego, CA: Academic Press.

Conflict of Interest Statement: The authors declare that the research was conducted in the absence of any commercial or financial relationships that could be construed as a potential conflict of interest.

Copyright (C) 2016 Jarque, Masner, Klánová, Prokeš and Bláha. This is an open-access article distributed under the terms of the Creative Commons Attribution License (CC $B Y)$. The use, distribution or reproduction in other forums is permitted, provided the original author(s) or licensor are credited and that the original publication in this journal is cited, in accordance with accepted academic practice. No use, distribution or reproduction is permitted which does not comply with these terms. 